\title{
Cultural Organizations and Communication in Portuguese Decentralization Policy
}

\author{
Maria João Anastácio Centeno \\ School of Media Studies and Communication, Lisbon, Portugal
}

\begin{abstract}
This paper intends to show the Portuguese municipalities' commitment, since the first decade of this century, in cultural facilities of municipal management and how it provided 12 of the 18 district capitals of mainland Portugal with cultural equipment, but after all we want to know if this effort resulted in a regular, diverse, and innovative schedule. Investing in urban regeneration, local governments have tried to convert cities' demographic changes (strengthening of the most educated and professionally qualified groups) in effective cultural demands that consolidate the three axes of development competitiveness-innovation-creativity. What the empirical study to the programming and communication proposals of those equipment shows is that it is not enough to provide cities with facilities; to escape to a utilitarian conception of culture, there is a whole work to be done so that such equipment be experienced and felt as new public sphere. Equipment in which proposals go through a fluid bind, constructed through space and discourse with local community, devoted a diversified and innovative bet full filling development axis. This paper presents in a systematic way what contributes to this binding on the analyzed equipment.
\end{abstract}

Keywords: culture, communication, innovation

\section{Introduction}

In 1999, precisely at the turn of a new century, the Portuguese Government launches, as part of the cultural policy of decentralization developed by the XIII Constitutional Government, the National Network of Theatres and Cine theatres. With the aim of providing the district capitals throughout Portugal with performance rooms, it is intended to improve access for all citizens to cultural values and goods. This is an example of a measure from the central state to promote the decentralization of cultural assets' supply, assuming that local authorities would, after the equipment's reformulation or construction, ensure its operation.

The growing investment of the central state in networks, which structure cultural life throughout the country (such as the National Network of Public Libraries started in 1986 and this National Network of Theatres and Cine theatres), has increased local authorities' action and resources. These measures have caused the Portuguese municipalities' cultural sectors' expenses to surpass the budget of the Ministry of Culture in a few years. In 2007, expenses amounted to 600 million Euros for local authorities against 300 million for the Ministry's budget. It is important to highlight that since its conception in 2000, the Operational Programme for Culture has facilitated this tendency. The Operational Programme for Culture began in the context of the III

Maria João Anastácio Centeno, Ph.D., associate professor, Communication Sciences Department, School of Media Studies and Communication. 
Community Support Framework (QCA III) for Portugal between 2000 and 2006, and provided, for the first time, an autonomous support for the cultural world. More specifically, thanks to its "2.1. Measure", it created and animated an Elementary Network of Cultural Areas. The programme contributed almost with 40 million of the 71 million Euros of estimated investments.

The success of this programme of national source and framework is dependent on the action of Portuguese municipalities. They are the ones that define the equipment model of management, finance programming actions, and all the other expenses related to its operation, in an attempt to boost the development of the cities that have been resorting to the logic of artistic creation as an element of distinction. Local government has tried to convert cities' demographic changes (strengthening of the most educated and professionally qualified groups) in effective cultural demands that consolidate the three axes of development: competitiveness-innovation-creativity.

This measure resulted in the rehabilitation of seven equipment and the construction of five more, which means that from the 18 district capitals of mainland Portugal, 12 have benefited with an equipment of municipal administration charged of providing a more or less regular schedule ${ }^{1}$.

The research developed in the 12 equipment ${ }^{2}$ shows that to provide cities with facilities is not enough to ensure access of all citizens to cultural goods. To escape to a utilitarian conception of culture, there is a whole work to be done so that equipment be experienced and felt as new public spheres.

Equipment in which proposals go through a fluid bind, constructed through space and discourse with local community, devoted a diversified and innovative bet, full filling developmental axis.

For binding, the role of the programmer is fundamental; he is a central tenet in the dynamics that characterizes the relationship of organizations with its audiences. He is the writer, or should be, of the proposed programme, being responsible for the intermediation between the organization and other agents, being the artists or audience; or, in Becker's (1982) words, he is the creator of an art world from establishing reciprocal relations. Familiarity with the cultural field gives him the right to discern the legitimate from the illegitimate, as well as producing "authorship discourses".

The aim of the programmer is always, ultimately, to persuade others to have made the right choice and suited to the characteristics of the equipment and surroundings. Addressing others implies him in an act of recognition animated of some intentionality: Others are to be placed in the direction of his proposals.

It is then his responsibility to provide a critical enjoyment, to propose not only artistic creation but also ways of approaching the sidelines of creation and the events' design conditions so that he could contribute to the revitalization of privileged spaces for debate and argumentative confrontation of ideas to broaden the participants' horizon of expectations.

\footnotetext{
${ }^{1}$ Although mainland Portugal has 18 districts, in the author's study, six capital cities were excluded: Lisboa "was not identified as a city in need and, indeed, it has cultural facilities, national or private well maintained and in operation” (Silva, 2004, p. 245), Évora and Viseu, because they have, since the mid-90s of last century, Regional Centers for Arts and Performance, Coimbra (the equipment built was eventually transferred to a theatre company and the city council participation confines itself to eight shows per year), Porto (the restored equipment was assigned to Teatro Nacional S. João and as such is directly under the Culture's Secretary of State, former Ministry of Culture) and Setúbal (the Forum Municipal Luisa Todi was refurbished and reopened in 2012; however, the work was made without public funding, which justifiesits exclusion from the universe of the study).

2 Teatro Aveirense, PaxJulia-Teatro Municipal de Beja, Theatro Circo de Braga, Teatro Municipal de Bragança, Cineteatro Avenida de Castelo Branco, Teatro Municipal de Faro, Teatro Municipal da Guarda, Teatro José Lúcio da Silva in Leiria, Centro de Artes do Espectáculo de Portalegre, Teatro Sá da Bandeira in Santarém, Teatro Municipal Sá de Miranda in Viana do Castelo e Teatro Municipal de Vila Real.
} 
Through the analysis of programme proposals during the first three years of operation of each equipment (mainly between 2004 and 2008) and interviews to those responsible for programming were possible to verify if the established relations consist of disruptive links or, otherwise, fluid links that result from the action's coordination of the involved parties not in isolation, but by behavioral expectations inter subjectively valid. It was thus possible to ascertain the type of relationship established between organizations and its audiences, in particular as regards the audience formation's policy (key part in the production of public cultural policies) and to what extent the type of relationship established can help overcome the reification of communicative practices that has threatened the Life world, the space of mutual respect and understanding, the "land of the immediate familiar”.

\section{Dialogical Practices}

The research assumes that through the discussion forums promoted by organizations it is possible to revitalize the public sphere, as in the XVIII century, a group of citizens developed critical sense and argumentative skills through participation in acts of publicity. This practice is, according to Habermas (1962), the ideal reference of the public and critical use of reason, in that from invoked reasons and under the force of the better argument, the individual is free to make his choice taking into view understanding. Rational discourse, as the last bastion of any possible justification and argumentation, is revalued as the practice that "convinces" us of what we can accept publicly in rational manner and of public as a critical instance.

Assuming that the goal of cultural policy is "to develop and maintain a cultural public sphere with organizations and subsidy schemes that optimize the possibility of the experiences of individual and social practice of citizens to express themselves culturally through art, aesthetics and other symbolic expressions" (Duelund, 2002, p. 18), the author proposes then that the practice of cultural organizations is viewed in a participatory manner; the relationship between organizations and the audience cannot be of instrumental nature, but dialogical, based on inter subjectivity of mutual understanding linguistically established. It means that the program practices of organizations affect but also are affected by a range of actors, those actors that become public when they become aware and active because they recognize a situation, engage in it and feel they are able to act against this situation, so the public are defined in terms of levels of interest in the affairs. What unites and holds together the members of an audience is a community of shared ideas and, above all, the consciousness of this communion.

As Habermas (1982) points out, the process of social life is not always supported by activities that can be described as communicational actions, "those symbolic manifestations (linguistic and non-linguistic) in which subjects capable of speech and action establish relationships with the intent to understand themselves about something and so coordinate their activities” (Habermas, 1982, p. 453). The process of social integration is not always founded on acts that presuppose inter subjective agreement, in which consensus is reached, not at the outset, but through the argumentative use of language itself.

However, the fact that individuals engage in certain types of activities and refer to them reflexively, puts them in the sense of understanding, since in supporting their decisions on interpretations, there will come a time when they have to defend them before others and reach an agreement.

Literature review allows the author to argue that is through educational services that cultural organizations better promote understanding. By not limiting themselves to present performances, but rather offering forms of ownership to how performances were designed, they meet the political dimension of organizations and 
transform them into active agents in the cultural public sphere. The reception of cultural works does not limit itself to the occasional consumption of already-made-products, but accompanies, "from within", the conditions and the processes of cultural production, the backstage, the techniques, rehearsals. By questioning works dimensions, educational services resize the reference system of actors, increasing the pleasures of proposals enjoyment. The interaction scenario so fitted is responsible for encouraging a dialogical practice that enriches the ability to choose by recommending actions aimed at understanding, communicational actions that correspond to the reciprocity between "ego" and "alter".

\section{Results}

The research to the organizations that comprise the National Network of Theatres and Cine theatres, more than 10 years after its launch, shows that there are equipment that act exclusively as presentation spaces rather than active agents in the cultural field, the field of social interaction in which different positions cohabit. Bourdieu (1989) notes: "Any current position can be defined in terms of a multidimensional system of coordinates whose values correspond to the values of different relevant variables” (p. 135). Managing cultural equipment means elect different variables as relevant. Programmers develop their activities on the overall volume of capital they possess and according to the relative weight of different species of capital they also have, what determines a bet on proposals more or less risky, more or less concerned with the degree of internationalization, the diversification of audience or civic affairs. Hence, "the position field is methodologically inseparable from the positions taken field, understood as a structured system of practices and agents expressions” (Bourdieu \&Wacquant, 1992, pp. 80-81).

When the programmer combines his duties with the responsibility for the Educational Service (cases of Braga, Bragança and Vila Real's equipment, all in the north of Portugal), when the programmer has little interference in the cultural field because his proposals are limited to select rather than produce or co-producing events (cases of Castelo Branco and Santarem's equipment, where the percentage of selected events and in-host is about $90 \%$ and Viana do Castelo which is around 99\%), when the programmer understands the work with local agents as the assignment of spaces (cases of Vila Real and Portalegre's equipment), when the involvement of the public is limited to publicize the range of activities proposed, it is an administered and utilitarian conception of culture that prevails.

It is in these circumstances that, as Adorno and Horkheimer (1944) pointed out, culture becomes a sphere of empty satisfactions responsible for the illegal participation of consumers for their own victimization and lack of opportunities to participate rationally in the process of needs satisfaction.

These are cases where cultural democratization is simply understood as the process of facilitating access to cultural goods; however making accessible does not automatically imply individuals' active ownership. Castelo Branco, Santarém and Viana do Castelo's equipment are examples of distorted public spheres to the extent that they meet cultural consumerism rather than a cumulative experience, since the dependence on the political-administrative system of local authorities (the management of these equipment is secured by the city council's departments and divisions) interfere in the process of social integration symbolically structured. The subjection to municipalities budgetary resources, the dependence on politic guidelines that submit the performance of the equipment to a political-electoral logic and the consequent relative autonomy to schedule distort the concept of public service and limit the possibility of being in the presence of equipment functioning professionally. 


\section{Conclusions}

This paper also shows that some activities proposed by other equipment effectively promote communicational actions, as the equipment implies something and by implying it simultaneously promote the coordination of action plans of the parties involved and contribute to the revitalization of action and dispute spaces. The understanding is, in these situations, the mechanism through which participants regulate their cooperation (ability to read the actions of others and respond appropriately) and hence the importance of individuals engaging in these proposals that promote a fluid bind, constructed spatial and discursively with local community.

The Faro and Guarda's equipment (the first is in Algarve, Portuguese most touristic area and the second is inside the center) give us examples of such proposal; the first is the equipment that has the highest number of activities performed by the Educational Service (29\% of total events), activities which include music and theatre performances, workshops, enacted visits to the theater, talks on topics related with performing arts for scholar, familiar and senior audiences and resulting from partnerships with local cultural agents. Guarda's equipment focuses on a risk programming, through the presentation and dissemination of alternative events, international projects (27\% of total events presented is of foreign origin), the diversity of audiences included (please note the organization of workshops within cycles and festivals, exhibitions, conferences, publishing activity, guided tours with workshops and other activities aimed at children, senior and excluded as prisoners and mental patients) and the number of productions, on average, four per month (under the various music festivals and the Project, the own structure of theatrical production). To the type of presented proposals we must add the fact that the route of those responsible for programming these two devices go through the cultural field gives them a privileged position to organize the equipment activity in a participatory manner and thus enhance competitiveness, innovation and creativity.

It is this type of proposal that meets the vector of democratization: the programming is characterized by a diverse offer and spaces are lived and embodied in population experience as social spaces that provide public ownership of these spaces that mediates the subsequent social production of conflicts and negotiations.

Thus, the Teatro Municipal da Guarda and the Teatro Municipal de Faro fulfill the mission of any cultural organization by restoring the collective experience of public sphere and therefore we consider them as “counter-institutions”, recovering Habermas expression, generated from Life world to stop the dynamics of economic and political-administrative action systems. It is through such examples that the primacy of culture as negotiation emerges, as a place where public sphere is recreated and we question our position in the world and where society, equated as a cluster of cooperative behavior developed by its members, is strengthened.

\section{References}

Adorno, T., \& Horkheimer, M. (1944). Dialécticado esclarecimento: Fragmentos filosóficos (Dialektik der Aufklärung: Philosophische fragmente) (Dialectic of enlightenment: Philosophical fragments). Rio de Janeiro: Zahar.

Barriga, S., \& Silva, S. G. da (Eds.). (2007). Serviços educativos na cultura (Educational services in culture). Porto, Sete Pés.

Becker, H. S. (1982). Art worlds. Berkeley and Los Angeles: University of California Press.

Bourdieu, P. (1989). O poder simbólico (Symbolic power). Lisboa: Difel.

Bourdieu, P., \& Wacquant, L. J. D. (1992). La logique des champs (The logic of fields). Réponses: Pour une anthropologie Réflexive (Replies: For a reflexive anthropology) (pp. 71-89). Paris: Seuil.

Bovone, L. (1997). Os novos intermediários culturais, considerações sobre a cultura pós-moderna (The new cultural intermediaries, considerations about postmodern culture). In C. Fortuna (Ed.), Cidade, cultura e globalização (City, culture and globalization) (pp. 105-120). Oeiras: Celta. 
Costa, I. A. (2008). Rivoli, 1989-2006. Porto: Ed. Afrontamento.

Costa, I. A. (2003). A vocação formadora e experimental de um teatro municipal (The formingand experimental vocation of a municipal theatre). In A. Domingues, I. Silva, I. Lopes, J. Teixeira, \& A. Semedo (Eds.), A cultura em acção, impactos sociais e território (The culturein action, social impacts and territory) (pp. 97-104). Porto: Ed. Afrontamento.

Cruz, D. I. (2008). De volta aos teatros, O contributo mecenático da Tabaqueira (Back to theatres, The contribution of Tabaqueira patronage). Porto: Livraria Civilização Editora.

Deputter, M. (2009). O que é um teatro municipal? (What is a municipal theatre?). Le Monde Diplomatique, 36, 24.

Duelund, P. (2002). On the public sphere as a cultural political idea, the Nordic cultural model as an example. Copenhagen: Nordic Cultural Institute.

Habermas, J. (1982). La Lógica de las ciencias sociales (ZurLogik der sozialwissenschaften) (On the logic of the social sciences). Madrid: Ed. Tecnos.

Habermas, J. (1981). Teoría de la acción comunicativa (Theorie des kommunikativen handelns) (The theory of communicative action) (2 vols.). Madrid: Taurus.

Habermas, J. (1962). A transformação estrutural da esfera pública (Strukturwandel der öffentlichkeit) (The structural transformation of the public sphere). Lisboa: FCG.

Madeira, C. (2002). Novos notáveis, os programadores culturais (New notables, the cultural programmers). Oeiras: Celta.

Pratley, D. (1995). The role of culture in local economic development. In M. L. L. Santos (Ed.), Cultura \& Economia, Actas do Colóquio Realizado em Lisboa (Culture \& Economy, Proceedings of the Symposium held in Lisbon) (pp. 241-252). Lisboa: Instituto de Ciências Sociais da Universidade de Lisboa.

Rebelo, J., Cristóvão, A., Madureira, L., CETRAD, \& UTAD. (2007). Teatro de Vila Real 2007, Visão dos residentes na região (Vila Real Theatre 2007, vision of regional residents). Vila Real: Teatro de Vila Real.

Silva, A. S. (2004). As redes culturais: Balanço e perspectivasda experiência Portuguesa, 1987-2003 (Cultural networks: Resultsand perspectivesofthe Portuguese experience, 1987-2003). In R. T. Gomes (Ed.), Públicos da cultura (Public of culture) (pp. 241-283). Lisboa: Observatório das Atividades Culturais. 